Altai State University

Rcta 3iwlogica Sibirica

Journal of Biology
Founded in 2015

\title{
New Records of a dangerus invasive pests - Brown marmorated stink bug Halyomorpha halys Stal, 1855 (Heteroptera, Pentatomidae) in Kazakhstan
}

\author{
I.I. Temreshev' ${ }^{1}$, P.A. Esenbekova ${ }^{2}$, A.M. Uspanov ${ }^{1}$ \\ ${ }^{1}$ LLP "Zh. Zhiembayev Kazakh SRI of Plant Protection and Quarantine named ", Ministry of Agriculture of \\ Republic of Kazakhstan, 050070, Almaty, Nauryzbaysky district, md. Rahat, Kultobe street, 1, Kazakhstan \\ ${ }^{2}$ Republican State Enterprise «Institute of Zoology» Committee of Science of the Ministry of Education and \\ Science of Kazakhstan, al-Farabi ave., Almaty, 93050060, Kazakhstan \\ temreshev76@mail.ru, esenbekova_periz@mail.ru, u_alibek@mail.ru
}

Brown marmorated stink bug Halyomorpha halys was first found in Kazakhstan in 2016. It is a dangerous invasive pest of agriculture. In Almaty and the Almaty oblast in 2017-2018, new finds of the Brown marmorated stink bug were made, which indicates the existence of its stable population in this region and the gradual expansion of the range of the species. A calendar of phenology of pest development in the southeast of Kazakhstan was compiled. Eating of egg-laying of Brown marmorated stink bug by ladybirds Propylea quatuordecimpunctata (Linnaeus, 1758) and Harmonia axyridis (Pallas, 1773) was noted.

Key words: Brown marmorated stink bug, Halyomorpha halys, Kazakhstan, biology, spreading of areal, invasive species, pest.

\section{Новые находки опасного инвазивного вредителя - мраморного клопа Halyomorpha halys Stal, 1855 (Heteroptera, Pentatomidae) в Казахстане}

\author{
И.И. Темрешев ${ }^{1}$, п.А. Есенбекова ${ }^{2}$, А.М. Успанов ${ }^{1}$ \\ ${ }^{1}$ ТОО «Казахский Научно-исследовательский институт защиты и карантина растений \\ им. Ж. Жиембаева» Министерства сельского хозяйства Республики Казахстан 050070, г. Алматы, \\ Наурызбайский район, мкр. Рахат, ул. Култобе, 1, Республика Казахстан \\ ${ }^{2}$ Республиканское государственное предприятие «Институт зоологии» Комитета науки \\ Министерства образования и науки Республики Казахстан, г. Алматы, пр. аль-Фараби, 93050060, \\ Республика Казахстан temreshev76@mail.ru, esenbekova_periz@mail.ru, u_alibek@mail.ru
}

\footnotetext{
Мраморный клоп Halyomorpha halys был впервые найден в Казахстане в 2016 г. Он является опасным инвазивным вредителем сельского хозяйства. В г. Алматы и Алматинской области были сделаны в 2017-2018 гг. новые находки мраморного клопа, что говорит о существовании его устойчивой популяции в этом регионе и постепенном расширении ареала вида. Составлен фенологический календарь развития вредителя на юго-востоке Казахстана. Отмечено поедание кладок яиц клопа божьими коровками Propylea quatuordecimpunctata (Linnaeus, 1758) и Harmonia axyridis (Pallas, 1773).
} 
Ключевые слова: Мраморный клоп, Halyomorpha halys, Казахстан, биология, расширение ареала, инвазивный вид, вредитель.

\section{Введение}

Мраморный клоп (коричнево-мраморный клоп, восточноазиатский мраморный клоп) Halyomorpha halys Stal, 1855 - опасный многоядный вредитель сельскохозяйственных, лесных и декоративных культур. Он относится к семейству Pentatomidae Leach, 1815 - Щитники, подотряда Heteroptera Latreille, 1810 - Клопы, отряда Нетірtеra Linnaeus, 1758 - Полужесткокрылые (Hoebeke, Carter, 2003; Rider, 2006). Название вида обусловлено окраской. Общий фон тела насекомого коричневый, спина и голова имеют бежевые «вкрапления», что визуально создает мраморный оттенок. Нижняя сторона тела - белая или бледно-коричневая, иногда с серыми или черными крапинками. От сходных видов из семейства щитников отличается более крупными размерами (длиной 10-17 мм) и характерным узором по краю брюшка. На последних 2-х сегментах усиков белые полоски. Ноги коричневые, также с белыми полосами (рис. 1). Самка клопа откладывает белые шаровидные яйца, размером от 1,3 до 1,6 мм, которые обычно прикрепляет к нижней стороне листа кучками по 20-30 штук (рис. 2, 3). После отрождения личинки могут оставаться в кладке на протяжении нескольких дней, вплоть до линьки на II возраст. Вид имеет 5 личиночных возрастов, на протяжении каждого из них личинки выглядят по-разному. Нимфы I возраста имеют оранжевую или красноватую окраску с черными пятнами и полосами (рис. 4а). Личинка II возраста становится тёмной, почти черной, с белыми пятнышками, и приобретает шипы по бокам тела и на голове (рис. 4b). В следующих возрастах она становится коричневато-белой или зеленовато-розовой (рис. 5a, b, c). Полный цикл развития клопа занимает 35-50 дней. Может давать до 6 поколений в год (в теплых широтах) (Zhimerikin, Guliy, 2014; Karpun et al., 2018; Neimorovets, 2018; Hoebeke, Carter, 2003; Wermelinger, Wyniger, Forster, 2008; Rice et al., 2014; EPPO Global Database, 2017).

Нативный ареал мраморного клопа включает страны Юго-Восточной Азии: Китай, КНДР, Южная Корея, Япония, Тайвань, Вьетнам (Zhimerikin, Guliy, 2014; Karpun et al., 2018; Neimorovets, 2018; Rider, 2006). Клоп является инвазивным видом, активно распространяющимся в последние годы по всему миру, в т.ч. и на постсоветском пространстве. Обнаружен в следующих странах: Лихтенштейн, Швейцария, Германия, Франция, Италия, Испания, Греция, Австрия, Венгрия, Румыния, Хорватия, Сербия, Словакия, Российская Федерация, Грузия, Казахстан, Соединенные Штаты Америки, Канада, Чили, о. Гуам, Новая Зеландия (Zhimerikin, Guliy, 2014; Esenbekova, Temreshev, 2016; Esenbekova, 2017; Karpun et al., 2018; Neimorovets, 2018; Frank, Biggs, 2013; EPPO Global Database, 2017). Из сопредельных с Казахстаном государств отмечен в Китайской Народной Республике и Российской Федерации (Краснодарский и Ставропольский край, Республика Адыгея). Вид входит в Единый перечень карантинных объектов Евразийского экономического союза и Европейской и Средиземноморской организации по защите растений (Zhimerikin, Guliy, 2014; Esenbekova, Temreshev, 2016; Esenbekova, 2017; Karpun et al., 2018; Neimorovets, 2018; Hoebeke, Carter, 2003; Wermelinger, Wyniger, Forster, 2008; Rice et al., 2014; EPPO Global Database, 2017). Может повреждать практически все плодовые и бахчевые культуры, ягодники, виноградники, декоративные растения, фасоль, сою, кукурузу, сорную растительность. В общей сложности для этого вида известно до 300 видов растений-хозяев из 49 семейств (Zhimerikin, Guliy, 2014; Karpun et al., 2018; Neimorovets, 2018; Frank, Biggs, 2013; EPPO Global Database, 2017). Питаясь соками растений, вредитель вызывает образование некротических пятен, опробковение повреждённых участков, формирование вдавлений на плодах, их преждевременное опадение и гниение. Из наиболее сильно повреждаемых культур указывают сою, грушу, персик, черешню, хурму, виноград, кукурузу, томаты и перец. Помимо прямого вреда, как и другие сосущие вредители, может переносить инфекционные заболевания растений. Осенью клопы, отыскивая укрытия для зимовки, проникают в жилые помещения, иногда в массе, вызывая у чувствительных людей аллергию и создавая дискомфорт выделением дурно пахнущего вещества (Zhimerikin, Guliy, 2014; Karpun et al., 2018; Neimorovets, 2018; Hoebeke, Carter, 2003; Wermelinger, Wyniger, Forster, 2008; Rice et al., 2014).

Первые экземпляры мраморного клопа были обнаружены в 2016 г. в Талгарском районе Алматинской области на посевах люцерны и сои. По материалам этих находок было сделано несколько публикаций в отечественных и зарубежных научных изданиях (Esenbekova, Temreshev, 2016; Esenbekova, 2017; Temreshev, Esenbekova, Muhamadiev, Sarsenbaeva, 2017; Esenbekova, Temreshev, Sagitov, Ageenko, 2018). На заседании Ученого совета Казахского НИИ защиты и карантина растений им. Ж. Жиембаева в марте 2018 г. генеральным директором д.б.н., профессором А.О. Сагитовым были продемонстрированы сотрудникам института экземпляры вредителя, а также сходные внешне виды клопов, распространенные в Казахстане (щитник весенний Rhaphigaster nebulosa (Poda, 1761) и др.). Им было также дано указание сотрудникам сделать фотографии объектов и взять данный вид на заметку. Мраморный клоп до сих пор не был включен в список вредных объектов, ограниченно распространенных на территории страны. В 2018 году при мониторинге посевов кормовых культур Алматинской области в рамках выполнения проектов МСX PK ВR06249249 «Разработка комплексной системы повышения продуктивности и улучшения племенных качеств сельскохозяйственных животных, на примере ТОО «Байсерке Агро»» по подпроекту 2. «Совершенствование технологий возделывания и заготовки кормовых культур» и 
BR06349590 «Создание инновационного агротехнологического парка для реализации точного земледелия», а также при работах в рамках проекта МОН РК АР 05135810 «Применение энтомопатогенных аскомицетов в качестве эндофитов сельскохозяйственных культур» последовали новые находки H. halys в новых местах на юговостоке Казахстана. Исходя из всего вышеизложенного, потребовалась подготовка настоящей работы.

\section{Материал и методы}

Материал был собран авторами в г. Алматы и Алматинской области с 2016 по 2018 годы. При сборе материала применяли стандартные энтомологические методики - кошение энтомологическим сачком, ручной сбор и визуальный осмотр. Кроме собственных сборов, были обработаны материалы д.б.н., профессора В.Л. Казенаса. Определение имаго и личинок мраморного клопа проводили И.И. Темрешев и П.А. Есенбекова. Для видовой идентификации вредителя, уточнения его таксономического положения, биологии, хозяйственного значения и распространения были использованы источники из списка литературы (Zhimerikin, Guliy, 2014; Esenbekova, Temreshev, 2016; Esenbekova, 2017; Karpun et al., 2018; Neimorovets, 2018; Hoebeke, Carter, 2003; Rider, 2006; Wermelinger, Wyniger, Forster, 2008; Cutting, Dieckhoff, Hoelmer, 2013; Talamas, Buffington, Hoelmer, 2013; Rice et al., 2014; EPPO Global Database, 2017). Определение личинок божьих коровок, поедавших кладки H. halys, проводилось И.И. Темрешевым с помощью определителя Г.И. Савойской (Savoyskaya, 1983). Для обоснования чужеродного статуса клопа применялись критерии чужеродного статуса (Orlova-Bienkowskaja, 2016). В разделе по материалу сокращены некоторые термины и названия: экз. - экземпляр, окр. - окрестности, г. - город, п. поселок, р-н - район, мкр. - микрорайон, пр. - проспект, ул. - улица, а также фамилии сборщиков - ИТ - И.И. Темрешев, ПЕ - П.А. Есенбекова, ВК - В.Л. Казенас, АУ - А.М. Успанов.

\section{Результаты}

Вредитель неоднократно отмечался в разных районах г. Алматы, а также в Талгарском районе Алматинской области на кормовых культурах, древесных декоративных и плодовых породах, а также вокруг и в жилых помещениях. В сентябре и октябре 2017 года H. halys массово проникали в жилые дома и общественные здания г. Алматы для зимовки. В день попадалось более 10-15 особей на балконе жилого дома в Аузовском районе г. Алматы, а также в здании Института зоологии (Бостандыкский район г. Алматы). Весной 2018 года зимующие особи обнаруживались в помещениях Наурызбайского района г. Алматы - они выходили из спячки и искали выход из них. Были найдены как кладки яиц, так и личинки имаго мраморного клопа (рис. 1-6). Собранный материал с указанием даты и места сбора, стадии развития, растения-хозяина, а также фамилии и инициалов коллектора приводится ниже:

\section{Алматинская область}

8.10.2016 - 1 личинка IV возраста, 1 личинка V возраста, Талгарский p-н, окр. п. Панфилов, на Glycine max, ПЕ, ИТ; 6.05.2017 - 4 экз., там же, на Medicago satíva, ПЕ, ИТ; 4.08.2017 - 1 экз., там же, на Glycine max, ПЕ; 5.08 .2017 - 3 экз., там же, на Glycine max и Zea mays, ПЕ, ИТ; 31.08.2017 - 1 зрелая кладка яиц, там же, на Glycine max, ИТ; 23.05.2018 - 1 свежеотложенная кладка яиц, там же, на Glycine max, ИТ; 6.06.2018 - 3 личинки II возраста, там же, на Medicago satíva, ПЕ, ИТ; 14.06.2018 - 2 личинки II возраста, Карасайский р-н, на Malus domestica, ИТ.

\section{г. Алматы}

6.07.2017 - 1 экз., Турксибский р-н, ул. Капальская, на ветви Prunus persica, ИТ; 8.11.2016 - 2 экз., Турксибский р-н, ул. Капальская, на стене здания, ИТ; 16.03.2017 - 1 экз., Ауэзовский р-н, ул. Куанышбаева, в подъезде жилого дома, ИТ; 11.07.2017 - 3 экз., Ауэзовский р-н, ул. Куанышбаева, на плодах Prunus domestica, ИТ; 13.09 .2017 - 1 личинка V возраста, Бостандыкский р-н, мкр. Пятилетка, на листе Vítis vinífera, ВК; 12.10.2017 - 2 экз., там же, на стене дома и в пластмассовой ёмкости, ВК; 20.10.2017 - 9 экз., Ауэзовский р-н, пр. Алтынсарина, ПЕ; 23.10.2017. - 5 экз., Бостандыкский р-н, пр. Аль-Фараби, Академгородок, окр. Института зоологии, ПЕ; 27.10.2017 - 8 экз., там же, ПЕ; 02.11.2017 - 10 экз., там же, ПЕ; 28-29.10.2017 - 11 экз., пр. Алтынсарина, Ауэзовский р-н, ПЕ; 30.10 .2017 - 10 экз., там же, ПЕ; 03.11.2017 - 12 экз., там же, ПЕ; 26.03.2018 - 2 экз., Наурызбайский р-н, мкр. Рахат, ул. Култобе, (1 живой на подоконнике, 1 мертвым в паутине паука Steatoda paykulliana Walckenaer, 1805), Ит; 7.04 .2018 - 1 кладка яиц, Ауэзовский р-н, ул. Шашкина, на листьях Aesculus hippocastanum, ИТ; 21.04 .2018 - 15 личинок І возраста, Бостандыкский р-н, ул. Тимирязева, на листьях Aesculus hippocastanum, ИТ; 22.05.2018 - 6 эк3., Ауэзовский р-н, пр. Алтынсарина, ПЕ; 27.05.2018 - 5 экз., там же, ПЕ; 07.06.2018 - 7 экз., там же, ПЕ; 13.06 .2018 - 3 кладки яиц (1 повреждена личинкой божьей коровки Propylea quatuordecimpunctata (Linnaeus, 1758)), 23 личинки I возраста, 19 личинок II возраста, Наурызбайский р-н, мкр. Рахат, ул. Култобе, на листьях Humulus lupulus и Vítis vinífera, AУ, Ит; 18.06.2018 - 3 кладки яиц (2 повреждены имаго и личинкой божьей коровки Harmonia axyridis (Pallas, 1773)), 20 личинок I возраста, 15 личинок II возраста, там же, на листьях Humulus lupulus и Vítis vinífera, ИТ, АУ; 26.06 .2018 - 1 экз., там же, мертвым на подоконнике, ИТ; 5.07.2018 - 1 кладка яиц, там же, на листьях Vítis vinifera, Ит; 23.08 .2018 1 личинка III возраста, 1 личинка IV возраста, Бостандыкский р-н, мкр. Коктем-1, мертвыми в сетях паука Phylloneta impressa (L. Koch, 1881), ИТ.

Исходя из найденного материала, были сделаны предварительные выводы по фенологии мраморного клопа в г. Алматы и Алматинской области. Выход имаго I поколения из зимней диапаузы происходит в середине-конце 
марта, в зависимости от погодно-климатических условий. Активные имаго встречаются по первую декаду ноября месяца включительно, затем уходят на зимовку. Яйцекладка сильно растянута, происходит с апреля по август. Личинки I возраста появляются в апреле-мае, последние личинки V возраста встречаются в октябре. Имаго II поколения появляются в июле-августе. Следовательно, фенологический календарь развития мраморного клопа на юго-востоке Казахстана будет выглядеть так (таблица 1):

Таблица 1 - Фенологический календарь развития мраморного клопа H. halys на юго-востоке Казахстана

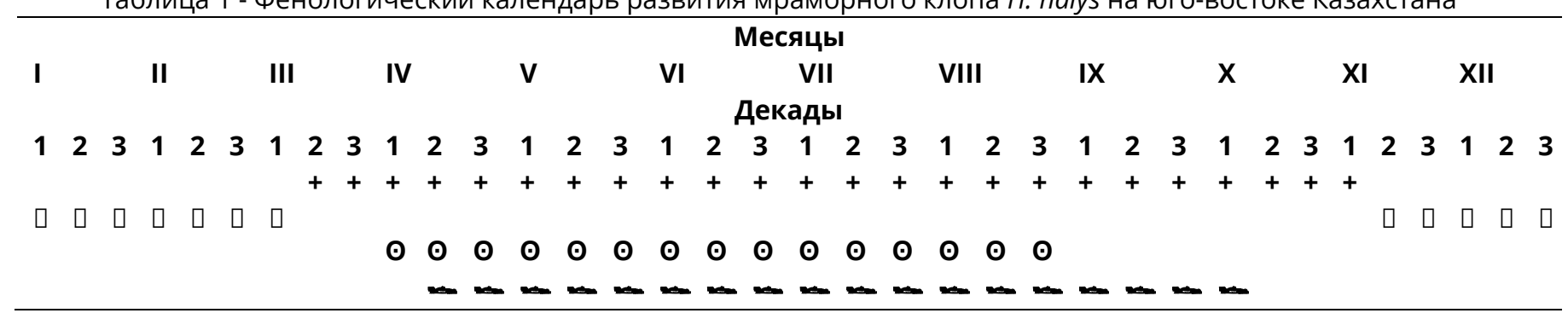

Условные обозначения: О - яйцо; - личинка; + - активное имаго; Р - зимующее имаго.

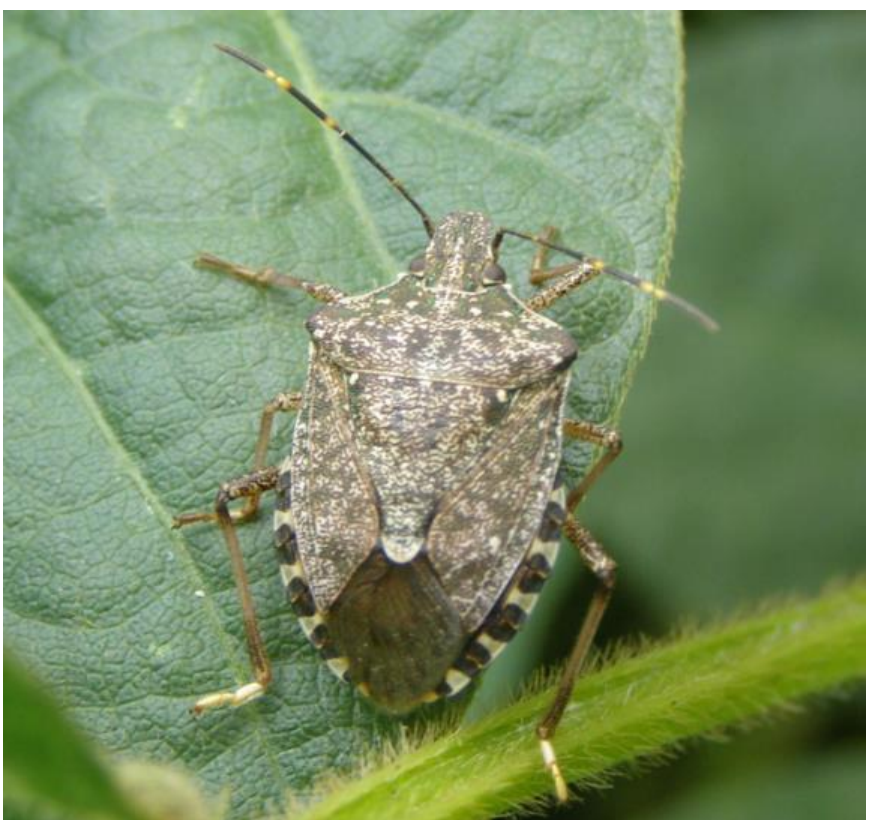

a

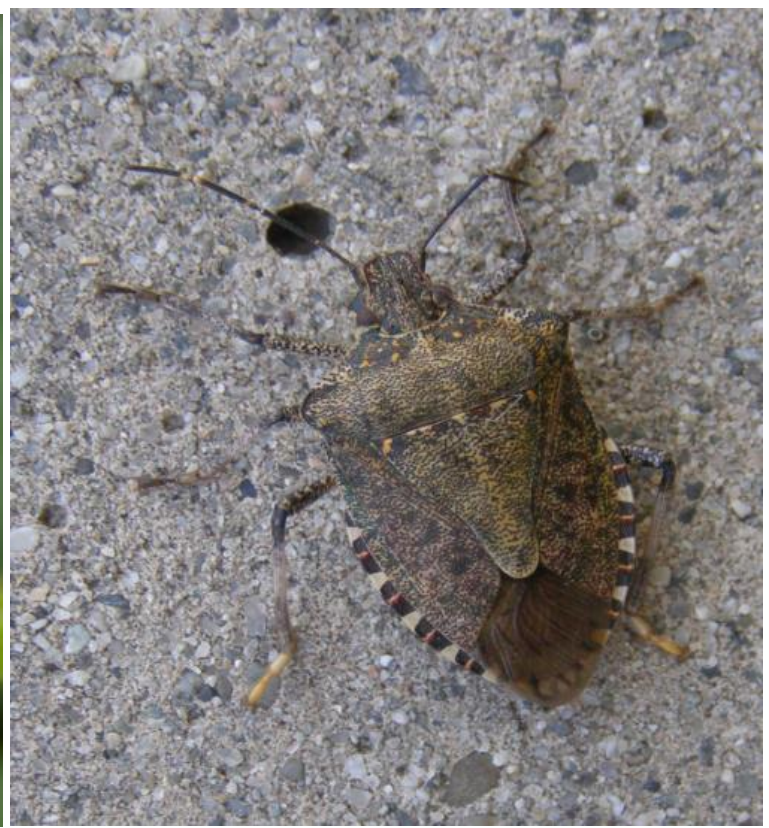

b

Рис. 1. Имаго мраморного клопа H. halys: a - клоп на растении сои (фото П.А. Есенбековой); b - клоп на стене здания (фото П.А. Есенбековой).

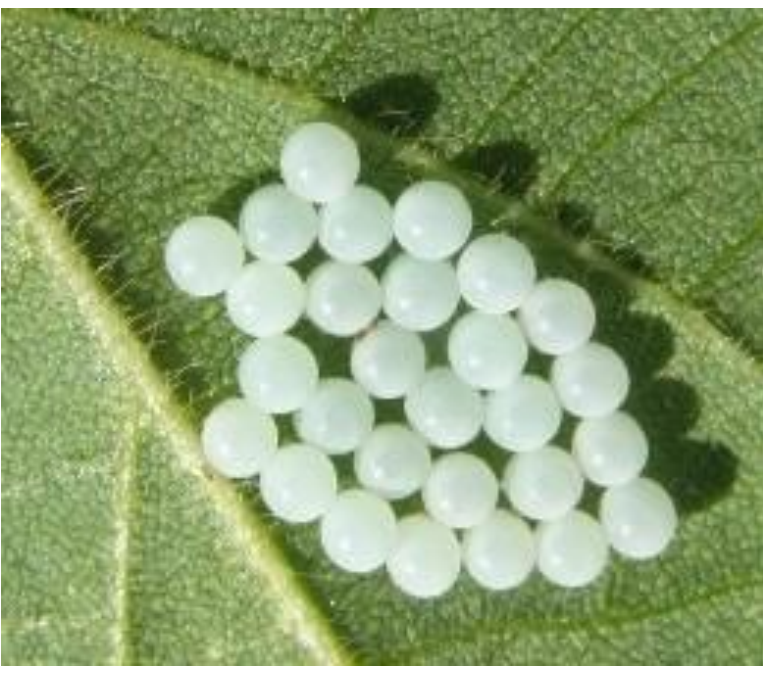

a

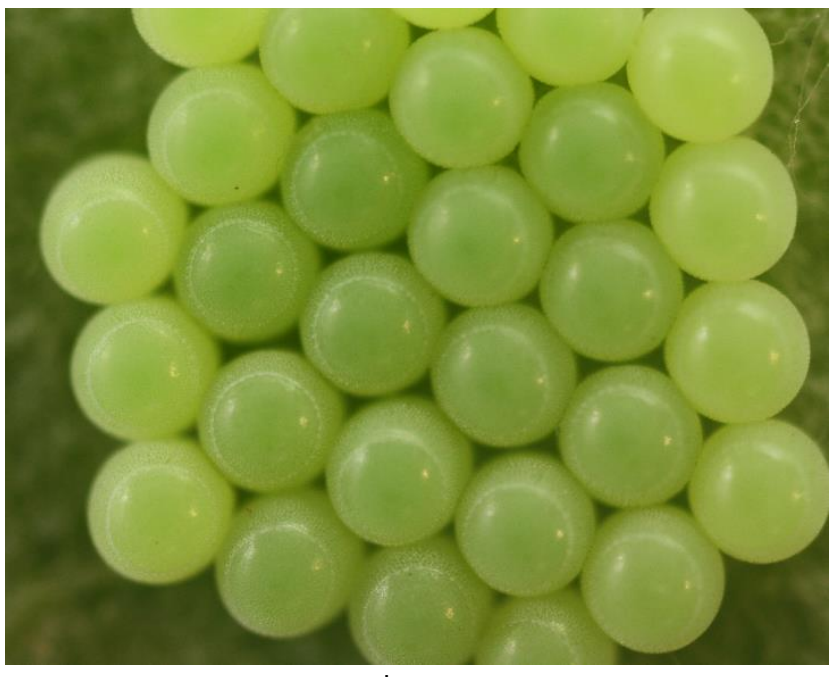

b

Рис. 2. Кладка мраморного клопа H. halys: a - на листе сои (фото П.А. Есенбековой); b - на листе винограда (фото А.М. Успанова). 


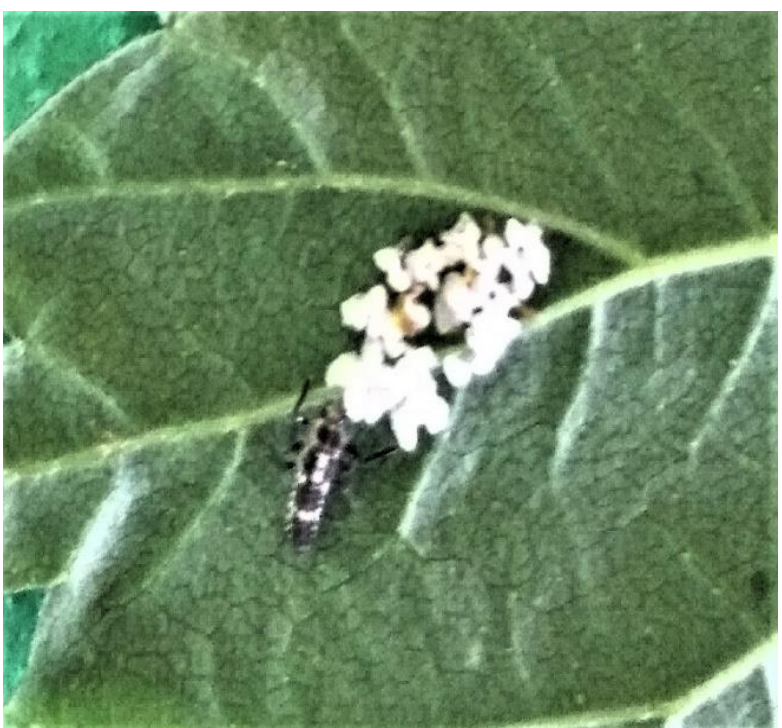

a

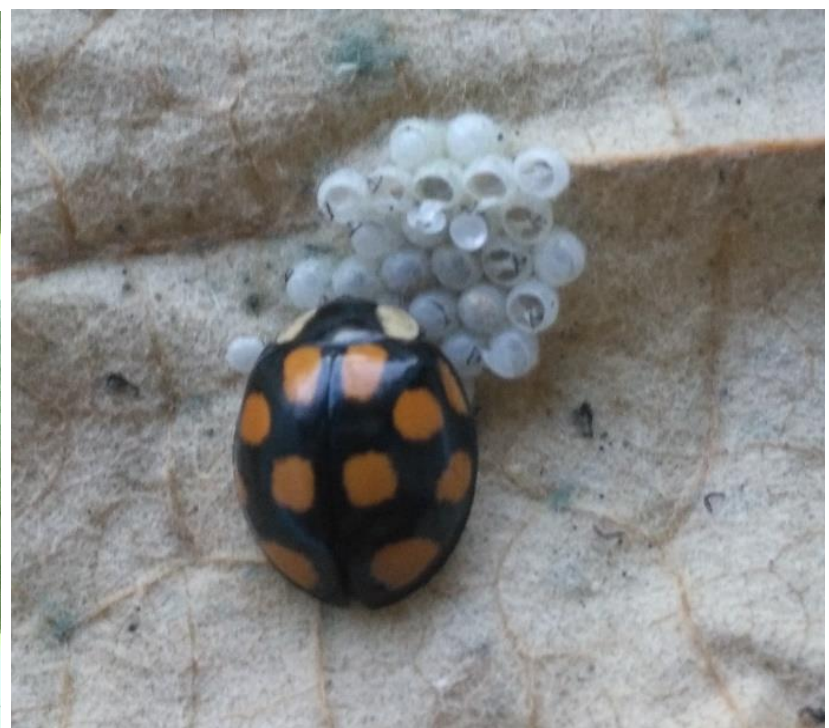

b

Рис. 3. Жуки-кокцинеллиды, поедающие кладки мраморного клопа H. halys: а - личинка Propylea quatuordecimpunctata (фото И.И. Темрешева); b - имаго Harmonia axyridis (фото И.И. Темрешева).

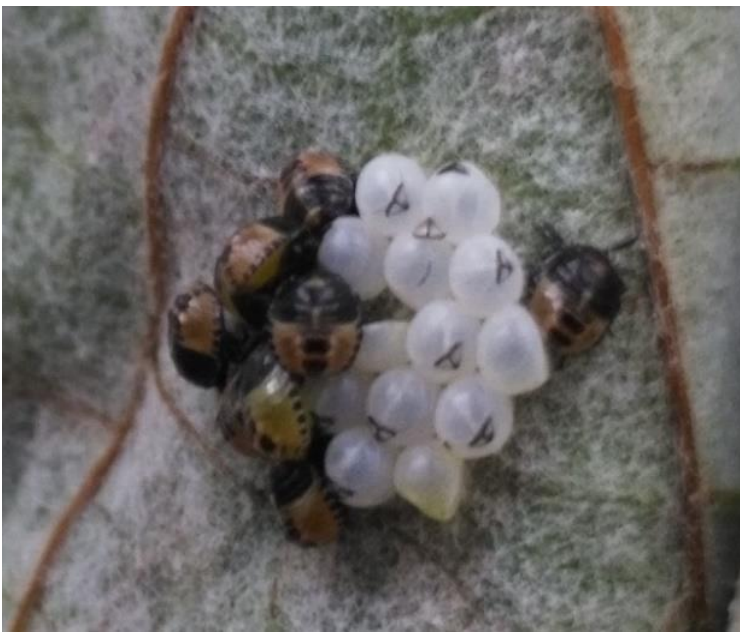

a

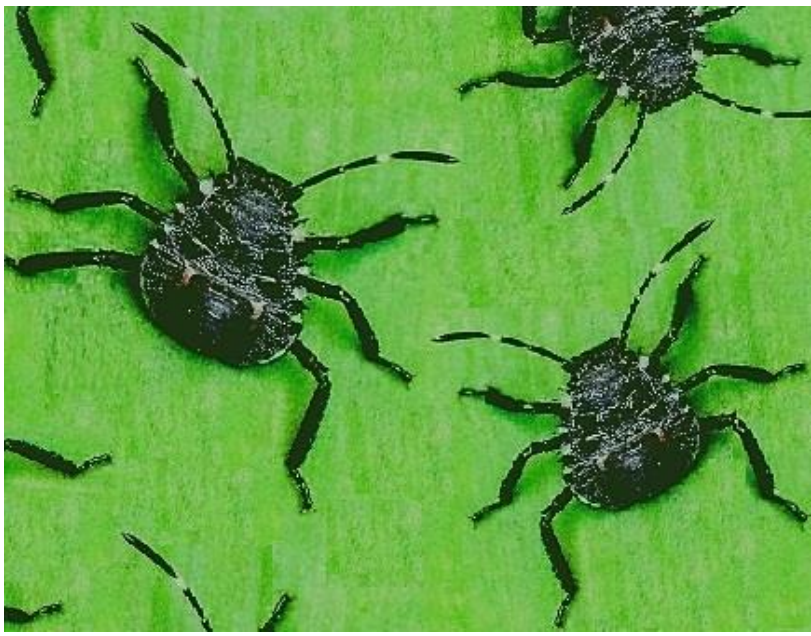

b

Рис. 4. Личинки мраморного клопа H. halys I (а) (фото А.М. Успанова) и II (b) (фото И.И. Темрешева) возраста.

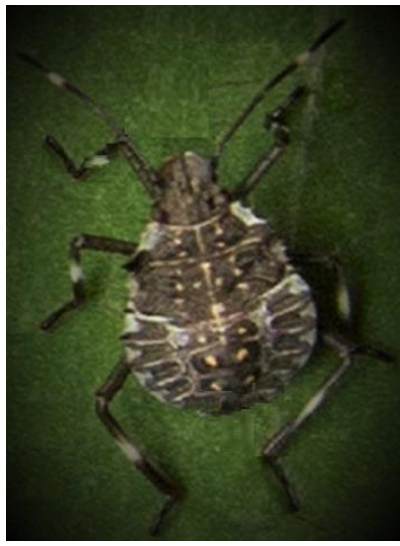

a

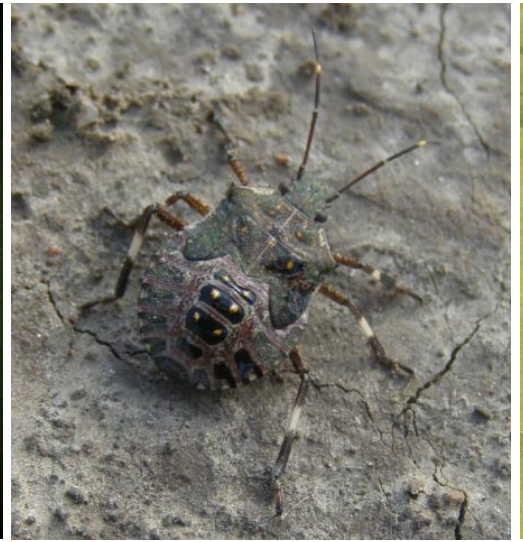

b

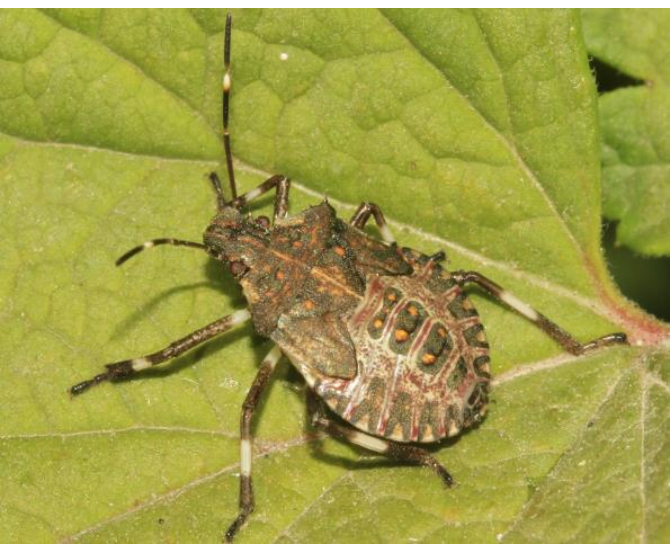

C

Рис. 5. Личинки мраморного клопа Н. halys: a - III возраста (фото И.И. Темрешева), b - IV возраста (фото П.А. Есенбековой); с - V возраста (фото В.Л. Казенаса). 


\section{Обсуждение результатов}

Обоснование чужеродного статуса $H$. halys: Вид ранее не отмечался в Казахстане, относительно недавно обосновался на юго-востоке страны, там имеется устойчивая самовоспроизводящаяся популяция. Он подпадает под 8 критериев чужеродности (Orlova-Bienkowskaja, 2016): 1. Обнаружение самовоспроизводящейся популяции вида на территории, где он раньше не был отмечен. 2. Дизъюнкция ареала, которую не удается объяснить дизъюнкцией ландшафтов или ареалов кормовых растений. 3. Расширение фрагмента ареала, изолированного от его основной части. 4. Локальное распространение в районе, примыкающем к инвазионным коридорам. 5. Акклиматизация в других регионах. 8. Обитание в антропогенных биотопах. 10. Отсутствие родственных видов в местной фауне при их наличии в фауне другого региона. 12. Наличие известных векторов переноса.

Пути инвазии: Наиболее вероятный начальный пункт инвазии мраморного клопа в Казахстан - Китайская Народная Республика. Между КНР и Казахстаном в обе стороны происходит довольно большое число перевозок разнообразных товаров, также очень часто граждане обоих стран ездят туда и обратно. В качестве подтверждения этой гипотезы можно использовать тот факт, что ближайшей точкой обитания двух других инвазивных видов насекомых, недавно проникших в Казахстан - жуков-зерновок Megabruchidius dorsalis Fahreus, 1839 и Acanthoscelides pallidipennis (Motschulsky, 1874) (Temreshev, Valiyeva, 2016а, b), является Синьцзянь-Уйгурский автономный район КНР. Ежемесячно оттуда в Казахстан поступает очень большое количество разнообразной продукции, в т.ч. растительной, и прибывает достаточно высокое число людей с большим объемом личного багажа. Это открывает достаточно большие возможности для проникновения и интродукции H. halys как с сельскохозяйственной продукцией и другими товарами, так и с багажом.

Новые находки мраморного клопа на территории г. Алматы и Алматинской области достаточно многочисленны и представлены как имаго, так и преимагинальными стадиями - кладками яиц и личинками разных возрастов. Это в очередной раз доказывает, что здесь имеется устойчивая самовоспроизводящаяся популяция вредителя, и вид уже прочно обосновался на юго-востоке Казахстана. Более того, обнаружение H. halys в новых местах свидетельствует о его расселении за пределы первичных очагов инвазии, в которых он был обнаружен. Если ранее клоп отмечался только в Талгарском районе Алматинской области и Турксибском районе г. Алматы, то теперь он найден в Карасайском районе Алматинской области и в Бостандыкском, Ауэзовском и Наурызбайском районах г. Алматы. На юго-востоке Казахстана в году отмечено развитие 2-х поколений вредителя. В случае его проникновения на юг страны, где условия более благоприятны, возможно развитие 3-х поколений.

В г. Алматы и Алматинской области выход имаго H. halys I поколения из зимней диапаузы происходит в середине-конце марта, в зависимости от погодно-климатических условий. В Российской Федерации, согласно имеющимся данным, выход из мест зимовки наблюдается с III декады апреля - II декады мая (в зависимости от региона) (Karpun et al., 2018). Таким образом, на юго-востоке Казахстана мраморный клоп проявляет свою активность, и, следовательно, вредоносную деятельность (поскольку после выхода из спячки насекомые проходят дополнительное питание), на месяц раньше. На юге страны, где теплый сезон наступает еще раньше, в случае его проникновения туда возможен выход вредителя с начала марта.

Отмеченные нами случаи поедания кладок клопа жуками-кокцинеллидами подтверждают уже имеющиеся данные зарубежных исследователей (Cutting, Dieckhoff, Hoelmer, 2013; Rice et al., 2014). Для выяснения того, насколько существенно воздействие, оказываемое ими на популяцию $H$. halys на юго-востоке Казахстана, требуются дополнительные исследования. Следует отметить интересный факт, что божья коровка Нагтопіа axyridis в юго-восточном Казахстане - тоже чужеродный вид (Orlova-Bienkowskaja et al., 2015). Таким образом, наблюдается возникновение экологических связей между видами-вселенцами - азиатской божьей коровкой и мраморным клопом. Питание яйцами $H$. halys именно для этого вида кокцинеллид было отмечено ранее американскими исследователями, а в США Harmonia axyridis также является вселенцем (Cutting, Dieckhoff, Hoelmer, 2013; Rice et al., 2014). Т.е., можно предполагать некие изначально существовавшие трофические связи между вредителем и энтомофагом в нативном ареале, которые проявляются при совместном попадании обоих видов в новые местообитания. Что касается паука S. paykulliana, то мраморный клоп является для него лишь случайной добычей, и попадает в его тенета только во время проникновения в жилые дома для зимовки либо при выходе оттуда. Похожая ситуация, по всей видимости, с пауком Ph. impressa, в сетях которого были обнаружены не имаго, а личинки H. halys - они являются для этого вида пауков не основной, а случайной добычей.

\section{Выводы}

В связи с большим объемом товарооборота и активной внешней и внутренней миграцией населения региона, не исключено дальнейшее распространение вредителя в другие области страны путем случайного завоза. Основными мишенями для дальнейшей инвазии H. halys в Казахстане являются Жамбылская, Туркестанская (бывшая Южно-Казахстанская) и Кызылординская области страны, где условия окружающей среды для него являются еще более благоприятными, чем в Алматинской области. Возможно, что пока его массовое размножение и расселение в какой-то степени сдерживают неблагоприятные погодно-климатические условия последних нескольких лет - затяжная холодная и дождливая весна. Поскольку вид до сих пор не включен в список 
карантинных объектов, ограниченно распространенных на территории Республики Казахстан, экономический порог вредоносности (ЭПВ) для него не установлен, не разработана система мониторинга и сигнализации начала проведения защитных мероприятий. Кроме того, в настоящее время в Списке пестицидов (ядохимикатов), разрешенных к применению на территории Республики Казахстан (List of pesticides..., 2013), для борьбы с мраморным клопом не зарегистрировано ни одного препарата. Ввиду того, что H. halys является многоядным вредителем, против него нужно будет провести регистрацию довольно большого количества химических инсектицидов на различных культурах, используя зарубежный опыт. Однако, при этом следует обязательно учитывать существующую информацию о резистентности вредителя к определенным препаратам, например, пиретроидам (Jacobs, Bernhard, 2009). Из биологических средств защиты растений, согласно существующим данным, достаточно эффективны энтомопатогенные грибы Metarhizium spp., Ophiocordiceps spp., Beaveria spp., Isaria spp. и энтомофаги - наездники-яйцееды Trissolcus spp. и Telenomus spp. из семейств Scelionidae и Platygastridae (Zhimerikin, Guliy, 2014; Cutting, Dieckhoff, Hoelmer, 2013; Talamas, Buffington, Hoelmer, 2013; Rice et al., 2014). Однако эти средства также отсутствуют в существующем Списке. Предпринятые нами попытки инкубации найденных кладок H. halys в лаборатории биотехнологии Казахского НИИ защиты и карантина растений им. Ж. Жиембаева с целью вывода из них наездников-яйцеедов пока не увенчались успехом, поскольку зараженных среди них не оказалось. Исходя из этого, соответствующим подразделениям Министерства сельского хозяйства Республики Казахстан следует в обязательном порядке предусмотреть закладку средств из госбюджета на разработку мер контроля его численности с учетом имеющегося зарубежного опыта.

\section{Благодарности}

Авторы выражают искреннюю благодарность д.б.н., профессору В.Л. Казенасу за предоставленные им сведения о находках и фотографию личинки мраморного клопа.

Также выражаем большую благодарность рецензенту рукописи статьи д.б.н. М.Ю. Орловой-Беньковской (Институт проблем экологии и эволюции им. А.Н. Северцова РАН, г. Москва) за ряд ценных советов и замечаний.

\section{References}

Bernon, G., Bernhard, K.M., Nielsen, A.L., Stimmel, J.F. et al. (2007). Host Range of the Exotic Brown Marmorated Stink Bug, Halyomorpha halys (Hemiptera: Pentatomidae): Implications for Future Distribution. Proceedings, 17th U.S. - Department of Agriculture Interagency Research Forum on Gypsy Moth and Other Invasive Species, 200, edited by K.W. Gottschalk, 26. Gen. Tech. Rep. NRS-P-10. Newtown Square, PA: U.S. Department of Agriculture. http://www.treesearch.fs.fed.us/pubs/12454.

Cutting, B., Dieckhoff, C., Hoelmer, K. (2013). Biological Control of the Brown Marmorated Stink Bug: Prospects and Procedures. USDA-ARS Beneficial Insects Introduction Research, Newark, DE, 42.

EPPO Global Database. Halyomorpha halys. (2017). https: // gd.eppo.int / taxon / HALYHA / distribution.

Esenbekova, P.A. (2017). First record of Halyomorpha halys (Stal, 1855) (Heteroptera, Pentatomidae) from Kazakhstan. Euroasian entomological journal, 16 (1), 23-24. (In Russian).

Esenbekova, P.A., Temreshev, I.I. (2016). Supplement to the fauna Hemiptera (Insecta, Heteroptera) in the fields of forage crops Almaty region. Materials of the international scientific and practical conference "Zoos of Kazakhstan, prospects and ways of development", November 3-4, 2016, Almaty: Nur-Print, 125-129. (In Russian).

Esenbekova, P.A., Temreshev, I.I., Sagitov, A.O., Ageenko, A.V. (2018). True bugs (Hemiptera, Heteroptera) on soybean crops in the Almaty region of Kazakhstan - pests and entomophages. 58th Scientific Session of the Institute of Plant Protection. National Research Institute, was held in Opalenica on 6-8th February, 2018. Poznan, 109.

Frank, D.L., Biggs, A.R. (2013). Control of Brown marmorated stink bug in Apple, 2012. Arthropod Management Tests, 38, 1-2.

Hoebeke, E.R., Carter, M.E. (2003). Halyomorpha halys (Stål) (Heteroptera: Pentatomidae): A Polyphagous Plant Pest from Asia Newly Detected in North America. Proceedings of the Entomological Society of Washington, 105 (1), $225-237$.

Jacobs, S.B., Bernhard, K. (2009). Brown Marmorated Stink Bug, Halyomorpha halys // https: // web.archive.org/web/20111007061426/http: // www.hgic.umd.edu / content / documents / BrownMarmoratedStinkBug.pdf

Karpun, N.N., Grebennikov, K.A., Protsenko, V.E., Aiba, L.Ya., Borisov, B.A., Mityushev, I.M., Zhimerikin, V.N., Ponomarev, V.L., Chekmarev, P.A., Dolzhenko, V.I., Karakotov, S.D., Malko, A.M., Govorov, D.N., Shtundyuk, D.A., Alive, A.V., Sapozhnikov, A.Ya., Abasov, M.M., Mazurin, E.S., Ismailov, V.Ya., Evdokimov, A.B. (2018). Brown marmorated stink bug Halyomorpha halys Stål in Russia: distribution, biology, identification, control measures. Moscow, 29. (In Russian). Russian).

List of pesticides, approved for use on the territory of the Republic of Kazakhstan for 2013-2022. (2013). Astana, 151. (In

Neimorovets, V.V. (2018). Brown marmorated stink bug Halyomorpha halys Stål (Heteroptera: Pentatomidae): morphology, biology, distribution and threats to agriculture in the Russian Federation (Analytical review). Plant Protection News, 1 (95), 11-16. (In Russian).

Orlova-Bienkowskaja, M. Ja. (2016). Is it possible to distinguish alien species of beetles (Coleoptera) from native ones? Entomological Review, 96 (3), 318-331 DOI 10.1134/S001387381603009X. 
Orlova-Bienkowskaja, M.J., Ukrainsky, A.S., Brown, P.M.J. (2015). Harmonia axyridis (Coleoptera: Coccinellidae) in Asia: a re-examination of the native range and invasion to southeastern Kazakhstan and Kyrgyzstan. Biological Invasions, 17 (7), 1941-1948. DOI 10.1007/s10530-015-0848-9

Rice, K.B., Bergh, Ch.J., Bergmann, E.J., Biddinger, D.J., Dieckhoff, C. et al. (2014). Biology, Ecology, and Management of Brown Marmorated Stink Bug (Hemiptera: Pentatomidae). Journal of Integrated Pest Menegment, 5 (3), 1-13.

Rider D. (2006). Family Pentatomidae Leach, 1815. In: Aukema B., Rieger Ch. (Eds): Catalogue of the Heteroptera of the Palaearctic Region. Vol. 5. Pentatomorpha II. The Netherlands Entomological Society, Amsterdam, 261.

Savoyskaya G.I. (1983). Larvae of ladybirds (Coleoptera, Coccinellidae) of the USSR fauna. Keys to the fauna of the USSR, published by the Zoological Institute of the USSR Academy of Sciences, L.: Science, Leningrad Branch, 137, 244. (In Russian).

Talamas, E.J., Buffington, M., Hoelmer, K. (2013). New synonymy of Trissolcus halyomorphae Yang. Journal of Hymenoptera Research, 33, 113-117.

Temreshev, I.I., Esenbekova, P.A., Mukhamadiev, N.S., Sarsenbaeva, G.B. (2017). A brief guide: pests of the feed crops in South-East Kazakhstan. Ed. A.O. Sagitov, Almaty: Taugul-Print, 117. (In Russian).

Temreshev, I.I., Valiyeva, B.G. (2016a). Megabruchidius dorsalis Fahreus, 1839 - invasive species in the fauna of seedbeetles (Coleoptera, Chrysomelidae, Bruchinae) of Kazakhstan. Euroasian entomological journal, 15, 2, 139-142. (In Russian).

Temreshev, I.I., Valiyeva, B.G. (2016b). Invasion of seed-beetle Acanthoscelides pallidipennis (Motschulsky, 1874) (Coleoptera, Chrysomelidae, Bruchinae) to Kazakhstan. Euroasian entomological journal, 15, 6, 527-529. (In Russian).

Wermelinger, B., Wyniger, D., Forster, B. (2008). First records of an invasive bug in Europe: Halyomorpha halys Stal (Heteroptera: Pentatomidae), a new pest on woody ornamentals and fruit trees? Mitteilungen der Schweizerischen Entomologischen Geselschaft, 81, 1-8.

Zhimerikin, V.N., Guliy, V.V. (2014). Brown marmorated stink bug. Protection and quarantine of plants, 4, 40-43. (In Russian).

\section{Citation:}

Temreshev, I.I., Esenbekova, P.A. Uspanov, A.M. (2018). New Records of a dangerus invasive pests - Brown marmorated stink bug Halyomorpha halys Stal, 1855 (Heteroptera, Pentatomidae) in Kazakhstan. Acta Biologica Sibirica, 4 (3), 94-101.

Submitted: 18.05.2018. Accepted: 05.07.2018

cross ref http:/ /dx.doi.org/10.14258/abs.v4i3.4413

(C) 2018 by the authors. Submitted for possible open access publication under the terms and conditions of the Creative Commons Attribution (CC BY) license (http://creativecommons.org/licenses/by/4.0/). 